\title{
The microbial coinfection in COVID-19
}

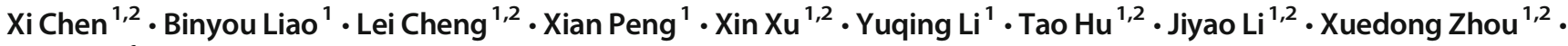 Biao Ren ${ }^{1}$}

Received: 4 June 2020 / Revised: 7 July 2020 / Accepted: 2 August 2020 / Published online: 11 August 2020

(C) Springer-Verlag GmbH Germany, part of Springer Nature 2020

\begin{abstract}
The severe acute respiratory syndrome coronavirus 2 (SARS-CoV-2), a novel $\beta$-coronavirus, is the main pathogenic agent of the rapidly spreading pneumonia called coronavirus disease 2019 (COVID-19). SARS-CoV-2 infects much more people, especially the elder population, around the world than other coronavirus, such as SARS-CoV and MERS-CoV, which is challenging current global public health system. Beyond the pathogenesis of SARS-CoV-2, microbial coinfection plays an important role in the occurrence and development of SARS-CoV-2 infection by raising the difficulties of diagnosis, treatment, prognosis of COVID19 , and even increasing the disease symptom and mortality. We summarize the coinfection of virus, bacteria and fungi with SARS-CoV-2, their effects on COVID-19, the reasons of coinfection, and the diagnosis to emphasize the importance of microbial coinfection in COVID-19.
\end{abstract}

\section{Key points}

- Microbial coinfection is a nonnegligible factor in COVID-19.

- Microbial coinfection exacerbates the processes of the occurrence, development and prognosis of COVID-19, and the difficulties of clinical diagnosis and treatment.

- Different virus, bacteria, and fungi contributed to the coinfection with SARS-CoV-2.

Keywords SARS-CoV-2 $\cdot$ COVID-19 $\cdot$ Coinfection · Microorganism

\section{Introduction}

The severe acute respiratory syndrome coronavirus 2 (SARSCoV-2) is a novel member of enveloped RNA $\beta$-coronavirus (Huang et al. 2020), which is the cause of a severe pneumonia with clinical symptoms different from known coronavirus caused pneumonia, such as SARS-CoV and MERS-CoV

$\mathrm{Xi}$ Chen and Binyou Liao contributed equally to this work.

Xuedong Zhou

zhouxd@scu.edu.cn

Biao Ren

renbiao@scu.edu.cn

1 State Key Laboratory of Oral Diseases \& National Clinical Research Center for Oral Diseases, Sichuan University, NO. 14, 3rd Section of Ren Min Nan Rd. Chengdu, Sichuan 610041, China

2 Department of Operative Dentistry and Endodontics, West China Hospital of Stomatology, Sichuan University, Chengdu 610041, China
(Lu et al. 2020; Zhu et al. 2020). The SARS-CoV-2 infection has become a public health challenge for all over the world. The SARS-CoV-2 caused pneumonia was named as coronavirus disease 2019 (COVID-19) by the World Health Organization (WHO) on 11 February 2020 (Castagnoli et al. 2020; Ni et al. 2020). The World Health Organization has declared the novel coronavirus outbreak a public health emergency of international concern. COVID-19 spreads rapidly and becomes a global pandemic. Until 3 July 2020, 217 countries and areas have been affected, and more than 10,710,000 cases have been confirmed globally with 517,877 deaths.

Since its first detection, the infection rate and mortality rate of the SARS-CoV-2 have far exceeded that of any other common flu ( $\mathrm{Li}$ et al. 2020a). Many drugs and vaccines specifically targeting SARS-CoV-2 infection are under different clinical phases. The coinfection of the SARS-CoV-2 with other microorganisms, such as virus, bacteria, and fungi, is a very important factor in COVID-19, and it can raise the difficulties of diagnosis, treatment, prognosis of COVID-19, and even increase the disease symptom and mortality (Ruuskanen et al. 2011) (Fig. 1). Currently, many trails and investigations 


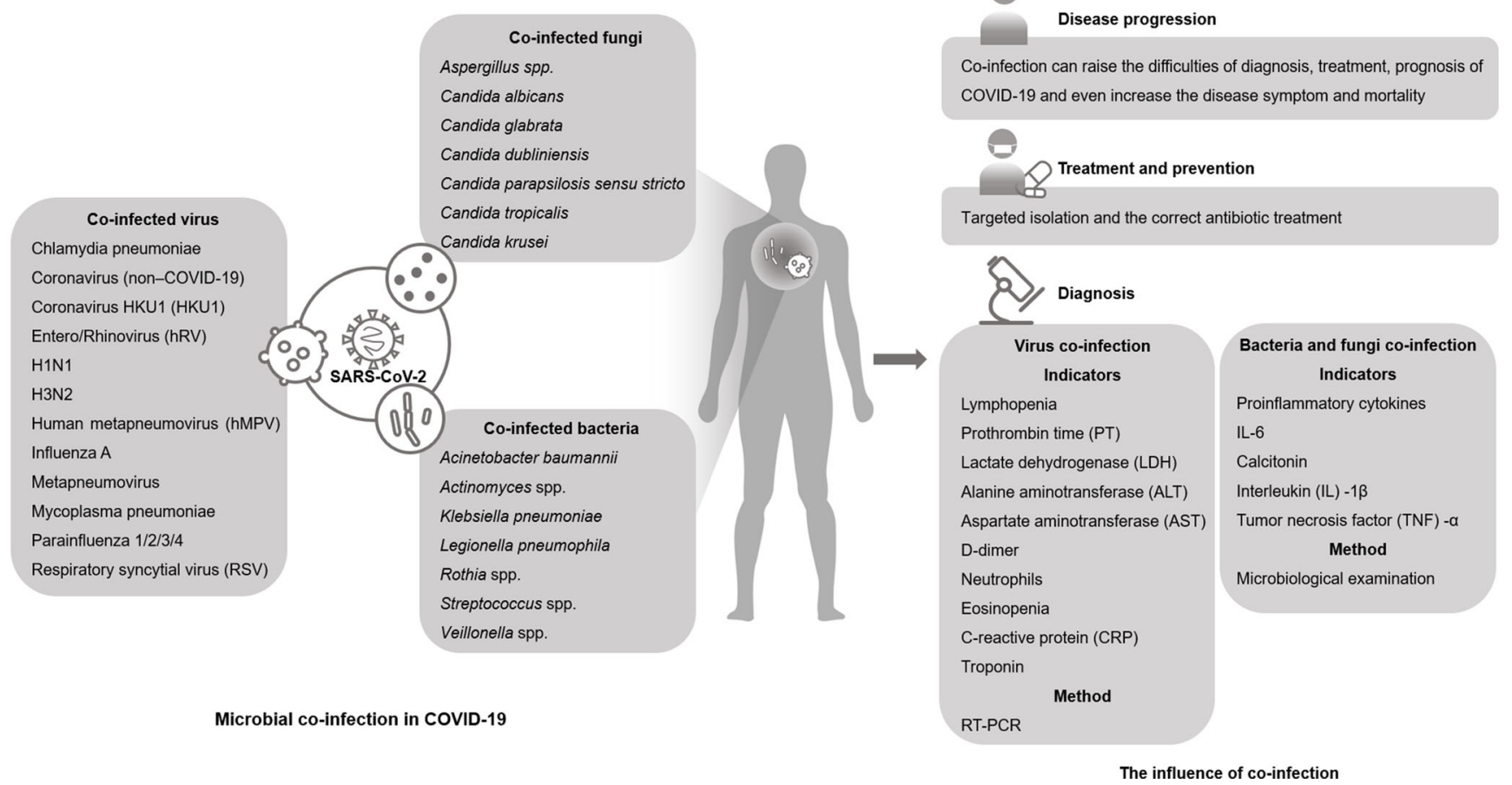

Fig. 1 In patients infected with SARS-CoV-2, coinfection of viruses, bacteria, and fungi is an important factor that cannot be ignored. Coinfection of SARS-CoV-2 with viruses, bacteria, and fungi will increase the difficulty of diagnosis, treatment, and prognosis of COVID-

19 , and even increase the symptoms and mortality of the disease. At the same time, coinfected microorganisms may also become a new strategy for the development of new treatments for SARS-CoV-2 infection

indicate the strong relationship between other virus, bacteria, fungi, and SARS-CoV-2 (Shen et al. 2020).

According to recent clinical studies, virus coinfection mainly includes respiratory virus such as entero/rhinovirus (hRV), human metapneumovirus (hMPV), respiratory syncytial virus (RSV), and other coronavirus (nonCOVID-19) (Lin et al. 2020). Coinfection can also change the intestinal homeostasis thus triggers the infection, and it stimulates immune cells to produce more severe inflammation. Gu et al. (2020) recently discovered that the intestinal bacterial diversity of patients with COVID-19 is significantly reduced, the relative abundance of opportunistic pathogens such as Streptococcus, Rothia, Veillonella, and Actinomyces are significantly higher, while the relative of beneficial symbionts abundance, such as Blautia, Romboutsia, Collinsella, and Bifidobacterium, is lower. Meanwhile, a descriptive study held by Chen et al. (2020) showed that the coinfected fungi includes Aspergillus spp., Candida albicans, and Candida glabrata (Table 1). Netea et al. (2020) found that in most individuals, SARS$\mathrm{CoV}-2$ infection is mild, while coinfection can increase the susceptibility of patients to severe disease by affecting the body's immune function. Meanwhile, Kalantar-Zadeh et al. (2020) hold the view that the ecosystem of commensal microbiota can both regulate and be regulated by invading viruses, facilitating either stimulatory or suppressive effects. More importantly, the coinfected microorganisms may also be a new

strategy for the development of new treatment of SARS-CoV2 infection. Therefore, we summarize the microbial coinfection of SARS-CoV-2, their effects on COVID-19, and the diagnosis to emphasize that the microbial co-infection is a nonnegligible factor in COVID-19, especially in the diagnosis and treatment.

\section{Viral coinfection with SARS-CoV-2}

Among viral infections of respiratory diseases, coinfection with other viruses is common. Many clinical studies have observed the viral co-infection with SARS-CoV-2 from different countries. Lin et al. (2020) conducted in vitro tests on 186 patient samples randomly selected from January 20 to February 1 in Shenzhen Third People's Hospital. Of the 92 SARS-CoV-2 positive patients, 6 patients (3.2\%) respectively detected viral coinfection. Four of them $(2.2 \%)$ detected at least two viruses (Lin et al. 2020). The common respiratory viruses including RSV, hRV, hMPV, parainfluenza virus type 2 (PIV2), and coronavirus HKU1 (HKU1) were also simultaneously detected. This data is consistent with a study of 5700 subjects that entero/rhinovirus and non-SARS-CoV-2 Coronavirus are the most common coinfected viruses, followed by RSV, parainfluenza 3, chlamydia pneumoniae, hMPV, influenza A, and mycoplasma pneumoniae (Richardson et al. 
Table 1 The microbial coinfection in COVID-19

\begin{tabular}{|c|c|c|}
\hline $\begin{array}{l}\text { Microbial } \\
\text { species }\end{array}$ & Coinfected microorganisms & References \\
\hline Virus & $\begin{array}{l}\text { Chlamydia pneumoniae } \\
\text { Coronavirus (nonCOVID-19) } \\
\text { Coronavirus HKU1 (HKU1) } \\
\text { Entero/rhinovirus (hRV) } \\
\text { H1N1 } \\
\text { H3N2 } \\
\text { Human metapneumovirus } \\
\quad \text { (hMPV) } \\
\text { Influenza A } \\
\text { Metapneumovirus } \\
\text { Mycoplasma pneumoniae } \\
\text { Parainfluenza } 1 / 2 / 3 / 4 \\
\text { Respiratory syncytial virus (RSV) }\end{array}$ & $\begin{array}{l}\text { (Lin et al. 2020) } \\
\text { (Richardson et al. 2020) } \\
\text { (Wang et al. 2020a, b) } \\
\text { (Kim et al. 2020) } \\
\text { (Zhang et al. 2020) }\end{array}$ \\
\hline Bacteria & $\begin{array}{l}\text { Acinetobacter baumannii } \\
\text { Actinomyces spp. } \\
\text { Klebsiella pneumoniae } \\
\text { Legionella pneumophila } \\
\text { Rothia } \text { spp. } \\
\text { Streptococcus spp. } \\
\text { Veillonella } \text { spp. }\end{array}$ & $\begin{array}{l}\text { (Zhang et al. 2020) } \\
\text { (Gu et al. 2020) } \\
\text { (Chen et al. 2020) }\end{array}$ \\
\hline Fungi & $\begin{array}{l}\text { Aspergillus spp. } \\
\text { Candida albicans } \\
\text { Candida glabrata } \\
\text { Candida dubliniensis } \\
\text { Candida parapsilosis sensu stricto } \\
\text { Candida tropicalis } \\
\text { Candida krusei }\end{array}$ & $\begin{array}{l}\text { (Verweij et al. 2020) } \\
\text { (Chen et al. 2020) } \\
\text { (Salehi et al. 2020) }\end{array}$ \\
\hline
\end{tabular}

2020). Another study in Wuhan showed that among 2745 SARS-CoV-2-positive patients, $5.8 \%$ of patients had coinfections with other coronavirus, influenza A virus, hRV, and influenza A H3N2 (Wang et al. 2020b). In Northern California, the researcher counted that in 116 specimens positive for SARS-CoV-2, 24 (20.7\%) were positive for one or more additional pathogens, and entero/rhinovirus, RSV, and nonSARS-CoV-2 Coronaviridae are the most common coinfected pathogens (Kim et al. 2020). Coinfection with other respiratory viruses may be an important reason for COVID19's early misdiagnosis as influenza for they almost have the same clinical manifestations, laboratory, and imaging findings (Lai et al. 2020b).

Due to the strong infectivity and wide spread of SARSCoV-2, in addition to other respiratory viruses coinfect with SARS-CoV-2, many systemic infectious virus, such as HIV (Blanco et al. 2020) and hepatitis virus (Kiley et al. 2020) coinfection, are also reported and raised the serious concern, but the infection rates are still unclear.
Among the viral coinfected population, the number of middle-aged and elderly people is relatively large, which may be related to their immunity and systemic disease status (Richardson et al. 2020). Wang et al. (2020b) found that the majority of COVID-19 patients were around 30-60 years old; the overall median age was 47 , while the median age of patients with coinfection was 51 . However, it is worth to notice that patients with SARS-CoV-2 coinfected with other viruses are not just elders or people with systemic diseases, healthy children, youth, and middle-aged people are also at risk from the coinfection (Lim et al. 2019).

\section{The influence of viral coinfection on disease progression and outcome}

Viral coinfection may have a great influence on treatment and prognosis of the disease. Coinfection is usually connected with the need for a higher level of care, increased length of stay (LOS), and development of acute respiratory distress syndrome (Cawcutt and Kalil 2017). Due to the coinfection has caused more serious damage to the immune system (Tay et al. 2020), patients, who are positive for SARS-CoV-2 and other viruses, condition may be more serious, the treatment is more complicated, and the treatment cycle is longer in general (Yang et al. 2020). A case report about a patient coinfected by SARS-CoV-2 and HIV had a longer progression of the disease and slower generation of specific antibody because of the collapse of immune system (Wang et al. 2020a). SARS-CoV-2 infection may also cause liver damage ( $\mathrm{Li}$ et al. 2020b). For patients who already have certain viral infections, such as hepatitis C virus and HIV, drug-induced liver injury (DILI) is more likely to occur (Boeckmans et al. 2020). The development and outcome of SARS-CoV-2 coinfected with other viruses are highly dependent on the host immune response, especially in the elderly (Nikolich-Zugich et al. 2020).

\section{Reason of viral coinfection and prevention}

The probability of respiratory virus coinfection varies from 10 to $68 \%$ (Nickbakhsh et al. 2019). Coinfection increases the levels of C-reactive protein (CRP) and procalcitonin (PCT) (Li et al. 2019). The coinfection mechanisms include virusinduced airway damage, reduced mucociliary clearance, and damage to the immune system (Vareille et al. 2011). Since many viruses can destroy the airway epithelium, this may cause an increase in viral coinfection (Denney and Ho 2018). Viruses can also cause immune system disorders to promote the possibility of infection by other viruses (Rouse and Sehrawat 2010). At present, it is difficult to determine the kinetics of viral coinfections since there is very little information about the virus kinetic parameters of SARS-CoV-2 infection. Current reports show that the coinfection rate of SARS- 
CoV-2 with other viruses is not high. The reason for this may be that the competitive advantage plays an important role in the coinfection process of SARS-CoV-2 and other respiratory viruses (Nowak et al. 2020).

In order to avoid the coinfection of SARS-CoV-2 and other viruses, the most important step is the prevention and control of infection (Yuen et al. 2020). To prevent the spread of infection, social distancing should be encouraged ( $\mathrm{Li}$ et al. 2020c; Yetmar et al. 2020). In the process of diagnosis and treatment for patients with other viral coinfections, it is best to provide a separate room for special people in the clinical setting to isolate and treat after understanding the risk of infection transmission (Alhazzani et al. 2020). Particularly, the patients, who previously infected with an HIV virus, are more likely to cause SARS-CoV-2 coinfection when the systemic immunity declines and specific antibody responses were delayed or even vanished. Therefore, for these patients, the importance of isolation should be more emphasized (Ferretti et al. 2020).

\section{The diagnosis of viral coinfection}

Among the SARS-CoV-2 patients, fever is the most common symptom, and more than $90 \%$ of patients have a fever (Singhal 2020); more than half have a cough (69.8\%), followed by dyspnea $(34.5 \%)$, myalgia $(27.7 \%)$, pharyngalgia $(17.4 \%)$, headache $(7.2 \%)$, diarrhea $(6.1 \%)$, sore throat $(6.1 \%)$, and rhinorrhea (4.0\%) (Nicola et al. 2020). The radiological imaging features of COVID-19 pneumonia include lung changes, for example, the ground-glass opacity (GGO) changes, and bronchial changes and pleural changes (Zhou et al. 2020b). These clinical symptoms and radiological imaging changes are similar to those with other respiratory viral infections. Therefore, it is difficult to determine the specific type and number of viruses the patient infected with based on imaging findings and medical history (Azekawa et al. 2020; Danis et al. 2020). These can lead to misdiagnosis of COVID19 and other respiratory diseases. The radiographic images and clinical symptoms can only be used as an auxiliary diagnosis, and patients cannot be diagnosed based solely on these two aspects.

In addition, laboratory data indicated that SARS-CoV-2 infection included lymphopenia, prolonged prothrombin time (PT), the elevation of lactate dehydrogenase (LDH), alanine aminotransferase (ALT), aspartate aminotransferase (AST), D-dimer, neutrophils, eosinopenia, C-reactive protein (CRP), and troponin (Qin et al. 2020). The most common laboratory findings are a decreased lymphocyte count and an increased high-sensitivity C-reactive protein level ( $\mathrm{Li}$ et al. 2020b). When combined with other viral infections, these results may change. The report shows that when SARS-CoV-2 and influenza A virus were coinfected, lymphocytes were increased, and C-reactive protein was often detected while the trend of lymphocytes was the opposite of SARS-CoV-2 infection alone. Of course, the results of laboratory tests are often affected by the degree of disease progression and the pathogens infected by the patient, so they can only be used as a reference for disease diagnosis.

Although there are many detection indicators, the most authoritative detection method is by using a multiplex reverse transcription-polymerase chain reaction (Mahony 2008), which can detect many respiratory tract infection viruses including the SARS-CoV-2 at the same time (D'Cruz et al. 2020). However, this method may cause some false negative results due to some factors during sample recovery, processing, or transportation. Therefore, the clinician has to repeat nasopharyngeal testing in order to confirm the diagnosis (World Health 2020). For patients with high clinical suspicion, sputum samples, or bronchoalveolar lavage should be considered in diagnosis (Rodriguez et al. 2020).

\section{Bacterial and fungal coinfection with SARS-CoV-2}

Bacterial and fungal coinfection are also common in viral pneumonia especially in critically ill patients (Zhou et al. 2020a). Among patients infected with respiratory viruses, the number of cases of primary coinfection or secondary bacterial pneumonia is between 11 and 35\% (Klein et al. 2016). In 2003, according to a cohort study investigated by Prof. Zhong Nanshan research team, more than $20 \%$ of the patients who were positive for SARS-CoV have bacterial and fungal coinfection, and the coinfected patients who received invasive operation can account for $70.6 \%$ (Zheng et al. 2003). In SARS-CoV patients, there are a variety of pathogens coinfected, while the negative bacilli and Candida are particularly the most common types of bacteria and fungi ( $\mathrm{Gu}$ and Korteweg 2007). For SARS-CoV-2, the phenomenon of bacterial and fungal coinfection also exists. Through a singlecenter, retrospective case series study including 55 severe patients and 166 nonsevere patients with laboratory-confirmed SARS-CoV-2 pneumonia, Zhang et al. (2020) found that in all 221 patients the bacterial coinfection rate is $7.7 \%$, and the fungal coinfection rate is $3.2 \%$. In the same situation as other viral pneumonia, the coinfection rate of severe patients is significantly higher than that of normal patients (Choi et al. 2012). In Guqin Zhang's study, the severely affected patients suffered a significantly higher rate of coinfection with bacteria (25.5\%) and fungus (10.9\%), while the bacterial and the fungal coinfection rates from the patients who were not severely affected are $0.8 \%$ and $0.6 \%$ respectively. Another study from Italy found that among the 16,654 patients with most severe diseases who deceased of SARS-CoV-2 infection, $11 \%$ of those cases were reported as coinfection with other bacteria and fungi (Huttner et al. 2020). In a retrospective, singlecenter study held by Chen et al. (2020) among the 99 cases 
of 2019 novel coronavirus pneumonia in Wuhan, the coinfected bacterias include Acinetobacter baumannii and Klebsiella pneumoniae while Aspergillus flavus, Candida glabrata, and Candida albicans are the most common coinfect fungus. Salehi et al. (2020) investigated 53 hospitalized COVID-19 patients with oropharyngeal candidiasis (OPC) and found that $C$. albicans was the most common pathogens, which counted for $70.7 \%$, followed by C. glabrata (10.7\%), C. dubliniensis (9.2\%), C. parapsilosis sensu stricto (4.6\%), C. tropicalis (3\%), and C. krusei (1.5\%).

It is common to see the gastrointestinal symptoms in COVID-19 patients, and both the RNA of SARS-CoV-2 and the live virus can be detected in the fecal of the patients. The infection of SARS-CoV-2 of intestinal cells can lead to the change of intestinal microbiota. Gu et al. (2020) identified the gut microbiome by $16 \mathrm{~S}$ ribosomal RNA (rRNA) gene V3-V4 region sequencing of 30 COVID-19 patients and found that compared with healthy people, the bacteria diversity had significantly reduced. The opportunistic pathogens such as Streptococcus, Rothia, Veillonella, and Actinomyces are significantly higher, while the relative of beneficial symbionts abundance, such as Blautia, Romboutsia, Collinsella, and Bifidobacterium, is lower (Gu et al. 2020). Zuo et al. (2020) analyzed the changes of fecal fungi in 30 Hong Kong COVID-19 patients during hospitalization showed that compared with healthy controls, the pathogenic fungi such as Candida spp. and Aspergillus spp. were significantly enriched in patients, and the intestinal fungal dysregulation could be continued until 12 days after the patient's nasopharyngeal sample was cleared of SARS-CoV-2.

Currently, clinical data show that the bacterial or fungal coinfection rate of SARS-CoV-2-infected patients is lower than that of other influenza virus infections. This may be due to the relatively few relevant clinical reports and the extensive use of antibiotics in early diagnosis of SARS-CoV-2 infection. However, it is certain that the infection rate of bacterial and fungal coinfection with SARS-CoV-2 is proportional to the severity of the disease (Garazzino et al. 2020), and the coinfection can increase the mortality (Bengoechea and Bamford 2020).

\section{Bacterial and fungal coinfection increases disease severity}

Coinfection with bacteria and fungi has a great influence on the progression and prognosis of the disease, especially in severe patients, which can lead to increased needs for intensive care, antibiotic treatment, and increased deaths (Kiedrowski and Bomberger 2018; Lim et al. 2019). In 2007, in the study of Bordetella pertussis and SARS-CoV coinfection, the gross and histopathological lung lesions of the coinfected group were more serious, and the coinfected group significantly upregulated the expressions and periods for proinflammatory cytokines, especially IL-6 and MCP-1 (Brockmeier et al. 2008) indicating that there is a synergistic effect between $B$. pertussis and SARS-CoV, which may partially explain the increased severity of pneumonia in patients with $B$. pertussis and SARS-CoV coinfection. Coinfection can increase the degree of systemic inflammation in the patient, thereby increasing the severity of the disease and delaying the cure time. In patients with COVID-19, the number of proinflammatory cytokines associated with severe lung injury, especially IL-6, has increased significantly (Tan et al. 2020). Moreover, the bacterial and fungal coinfection was associated with a 2.5-fold increase in the risk of death in SARS-CoV-2 (Martins-Filho et al. 2020) indicating that there is a certain interaction between bacteria or fungi and SARS-CoV-2.

\section{The reason of bacterial or fungal coinfection and the antibiotic treatment}

SARS-CoV-2 infection can damage lymphocytes, especially B cells, T cells, and NK cells, which will lead to the immune system's impairment during the period of disease (Wang et al. 2020a). The decrease of lymphocytes and host immune function may be the main reason for the coinfection (Luo et al. 2019). The mortality is more significant in severe cases compared with the nonsevere group (Qin et al. 2020) due to the higher coinfection rate in severe patients. For more severely ill patients, they are more likely to receive treatment with invasive catheters, resulting in increased sensitivity to secondary infections with multidrug-resistant pathogens such as Acinetobacter baumannii, Escherichia coli, Pseudomonas aeruginosa, and Enterococcus spp. (Rawson et al. 2020).

Although SARS-CoV-2 is virus-derived, based on the experience of overlapping bacterial infections in influenza, antibiotic treatment for patients with SARS-CoV-2 seemed to be the basic principle (Piva et al. 2020). According to the current data about patients with viral pneumonia, bacterial or fungal coinfection may be related to the significant risk of delaying appropriate treatment, which then lead to an increase in the mortality rate (Bengoechea and Bamford 2020). The consideration of antibiotic treatment in critically ill patients with COVID-19 is advisable as the bacterial infection cannot be excluded (Bassetti et al. 2020). A large number of studies have shown that during COVID-19 pandemic, antibiotic prescriptions were extensive and excessive during treatment, and 90\% of patients prescribed empirical antibiotics (Lai et al. 2020a). However, the coinfected bacterial and fungal species in SARS-CoV-2 patients have not been fully investigated and reported so far. Of the hundreds of published articles on SARS-CoV-2 with clinical data, only a few reported the coinfections of bacteria and fungus but did not identify the detail pathogens. The widespread and inappropriate use of antibiotics is likely to lead to antibiotic resistance (AMR), which has a major impact on global health and the world 
economy (Aslam et al. 2018; Prestinaci et al. 2015). Therefore, we recommend empirical treatment based on the clinical symptoms of coronavirus patients, choosing the most appropriate antibacterial agent according to local guidelines and local drug sensitivity models, and degrade as early as possible based on microbiological results or stop misapplication of antibiotics (Årdal et al. 2020).

\section{The diagnosis of bacterial and fungal coinfection}

For the diagnosis of COVID-19 patients, there are a lot of clinical guidelines. However, little attention was paid to the bacterial and fungal coinfection of this disease, and the standardized testing process of coinfection is still unavailable. It is difficult to distinguish bacterial or fungal infections from existing viral pneumonia based on clinical and radiological performance (Azoulay et al. 2020). In addition, there are articles indicating that calcitonin may also be an auxiliary means for detecting whether there is bacterial or fungal coinfection (Wiegers et al. 2019) as the concentration of interleukin (IL)$1 \beta$, tumor necrosis factor (TNF)- $\alpha$, and IL-6 increases, which results in the massive production and release of parathyroidderived calcitonin during bacterial infection. However, the synthesis of parathyroid-derived calcitonin is inhibited by (TNF) $-\gamma$, which secretion is increased during viral infection (Lippi and Plebani 2020). Therefore, the large increase of calcitonin will reflect the overlapping infection of bacteria in patients who have developed serious diseases, leading to the complication of clinical conditions (Martins-Filho et al. 2020). In addition, the microbiological examination is a practical way for diagnosis, especially sputum culture (Budayanti et al. 2019). However, taking sputum or blood samples from SARS-CoV-2-infected patients may pose a significant risk to biological sample collectors and laboratory technicians as the SARS-CoV-2 does not only spread through respiratory droplets and direct contact but also through virus-laden aerosols (Peng et al. 2020; Xu et al. 2020). Therefore, it is very necessary to establish a standard detection measure for the coinfection of bacteria or fungi and to provide adequate protective measures for relevant persons.

\section{Conclusion}

The coinfection between different microorganisms and SARS-COV-2 is a serious problem in the COVID-19 pandemic. However, there are few reports about SARS-CoV-2 coinfects with bacteria, fungus, and other viruses. The clinical data of SARS-CoV-2 coinfection are of great value in guiding evidence-based treatment of COVID-19. Patients with severe SARS-CoV-2 infections, including other viruses, bacteria, and fungi, have a significantly higher rate of coinfection than those who have not been seriously affected. Therefore, under the premise of not jeopardizing the safety of laboratory personnel, it is necessary to strengthen the investigation of the coinfection of patients with COVID-19. It provides a theoretical and factual basis for precise treatment, accurate prevention, and treatment of infectious complications and an effective reduction of the mortality rate of coronavirus-infected patients.

Authors' contributions X.Z. and B. R. conceived and designed the structure of this review; X.Z., XC, BL., L.C., X.P., X.X., Y.L., T.H., J.L., and B.R. wrote the manuscript; X.Z. revised the manuscript.

Funding information This study was supported by Special Funds for Prevention and Control of COVID-19 of Sichuan University (2020scunCoV-10008, XZ).

\section{Compliance with ethical standards}

Conflict of interest The authors declare that they have no conflict of interest.

Ethics approval The present work did not include any animal or human samples or patient data.

Consent to participate and consent for publication All authors and institutions where the work was carried out have approved the content and authorship of the manuscript.

\section{References}

Alhazzani W, Møller MH, Arabi YM, Loeb M, Gong MN, Fan E, Oczkowski S, Levy MM, Derde L, Dzierba A, Du B, Aboodi M, Wunsch H, Cecconi M, Koh Y, Chertow DS, Maitland K, Alshamsi F, Belley-Cote E, Greco M, Laundy M, Morgan JS, Kesecioglu J, McGeer A, Mermel L, Mammen MJ, Alexander PE, Arrington A, Centofanti JE, Citerio G, Baw B, Memish ZA, Hammond N, Hayden FG, Evans L, Rhodes A (2020) Surviving sepsis campaign: guidelines on the management of critically ill adults with Coronavirus Disease 2019 (COVID-19). Intensive Care Med 46(5):854-887. https://doi.org/10.1007/s00134-020-06022-5

Årdal C, Balasegaram M, Laxminarayan R, McAdams D, Outterson K, Rex JH, Sumpradit N (2020) Antibiotic development - economic, regulatory and societal challenges. Nat Rev Microbiol 18(5):267274. https://doi.org/10.1038/s41579-019-0293-3

Aslam B, Wang W, Arshad MI, Khurshid M, Muzammil S, Rasool MH, Nisar MA, Alvi RF, Aslam MA, Qamar MU, Salamat MKF, Baloch Z (2018) Antibiotic resistance: a rundown of a global crisis. Infect Drug Resist 11:1645-1658. https://doi.org/10.2147/idr.S173867

Azekawa S, Namkoong H, Mitamura K, Kawaoka Y, Saito F (2020) Coinfection with SARS-CoV-2 and influenza A virus. IDCases 20: e00775. https://doi.org/10.1016/j.idcr.2020.e00775

Azoulay E, Russell L, Van de Louw A, Metaxa V, Bauer P, Povoa P, Montero JG, Loeches IM, Mehta S, Puxty K, Schellongowski P, Rello J, Mokart D, Lemiale V, Mirouse A (2020) Diagnosis of severe respiratory infections in immunocompromised patients. Intensive Care Med 46(2):298-314. https://doi.org/10.1007/ s00134-019-05906-5

Bassetti M, Giacobbe DR, Aliberti S, Barisione E, Centanni S, De Rosa FG, Di Marco F, Gori A, Granata G, Mikulska M, Petrosillo N, Richeldi L, Santus P, Tascini C, Vena A, Viale P, Blasi F (2020) 
Balancing evidence and frontline experience in the early phases of the COVID-19 pandemic: current position of the Italian Society of anti-infective therapy (SITA) and the Italian Society of Pulmonology (SIP). Clin Microbiol Infect 26(7):880-894. https:// doi.org/10.1016/j.cmi.2020.04.031

Bengoechea JA, Bamford CGG (2020) SARS-CoV-2, bacterial co-infections, and AMR: the deadly trio in COVID-19? EMBO Mol Med doi: $10.15252 / \mathrm{emmm} .202012560$

Blanco JL, Ambrosioni J, Garcia F, Martínez E, Soriano A, Mallolas J, Miro JM (2020) COVID-19 in patients with HIV: clinical case series. Lancet HIV 7(5):e314-e316. https://doi.org/10.1016/s23523018(20)30111-9

Boeckmans J, Rodrigues RM, Demuyser T, Piérard D, Vanhaecke T, Rogiers V (2020) COVID-19 and drug-induced liver injury: a problem of plenty or a petty point? Arch Toxicol 94(4):1367-1369. https://doi.org/10.1007/s00204-020-02734-1

Brockmeier SL, Loving CL, Nicholson TL, Palmer MV (2008) Coinfection of pigs with porcine respiratory coronavirus and Bordetella bronchiseptica. Vet Microbiol 128(1-2):36-47. https:// doi.org/10.1016/j.vetmic.2007.09.025

Budayanti NS, Suryawan K, Iswari IS, Sukrama DM (2019) The quality of sputum specimens as a predictor of isolated bacteria from patients with lower respiratory tract infections at a tertiary referral hospital, Denpasar, Bali-Indonesia. Front Med (Lausanne) 6:64. https://doi. org/10.3389/fmed.2019.00064

Castagnoli R, Votto M, Licari A, Brambilla I, Bruno R, Perlini S, Rovida F, Baldanti F, Marseglia GL (2020) Severe acute respiratory syndrome coronavirus 2 (SARS-CoV-2) infection in children and adolescents: a systematic review. JAMA Pediatrics. https://doi.org/10. 1001/jamapediatrics.2020.1467

Cawcutt K, Kalil AC (2017) Pneumonia with bacterial and viral coinfection. Curr Opin Crit Care 23(5):385-390. https://doi.org/10.1097/ mcc.0000000000000435

Chen N, Zhou M, Dong X, Qu J, Gong F, Han Y, Qiu Y, Wang J, Liu Y, Wei Y, Xia J, Yu T, Zhang X, Zhang L (2020) Epidemiological and clinical characteristics of 99 cases of 2019 novel coronavirus pneumonia in Wuhan, China: a descriptive study. Lancet 395(10223): 507-513. https://doi.org/10.1016/s0140-6736(20)30211-7

Choi SH, Hong SB, Ko GB, Lee Y, Park HJ, Park SY, Moon SM, Cho OH, Park KH, Chong YP, Kim SH, Huh JW, Sung H, Do KH, Lee SO, Kim MN, Jeong JY, Lim CM, Kim YS, Woo JH, Koh Y (2012) Viral infection in patients with severe pneumonia requiring intensive care unit admission. Am J Respir Crit Care Med 186(4):325-332. https://doi.org/10.1164/rccm.201112-2240OC

Danis K, Epaulard O, Bénet T, Gaymard A, Campoy S, Bothelo-Nevers E, Bouscambert-Duchamp M, Spaccaferri G, Ader F, Mailles A, Boudalaa Z, Tolsma V, Berra J, Vaux S, Forestier E, Landelle C, Fougere E, Thabuis A, Berthelot P, Veil R, Levy-Bruhl D, Chidiac C, Lina B, Coignard B, Saura C (2020) Cluster of coronavirus disease 2019 (Covid-19) in the French Alps, 2020. Clin Infect Dis 71: 825-832. https://doi.org/10.1093/cid/ciaa424

D'Cruz RJ, Currier AW, Sampson VB (2020) Laboratory testing methods for novel severe acute respiratory syndrome-coronavirus-2 (SARSCoV-2). Front Cell Dev Biol 8:468. https://doi.org/10.3389/fcell. 2020.00468

Denney L, Ho LP (2018) The role of respiratory epithelium in host defence against influenza virus infection. Biomed J 41(4):218-233. https://doi.org/10.1016/j.bj.2018.08.004

Ferretti L, Wymant C, Kendall M, Zhao L, Nurtay A, Abeler-Dörner L, Parker M, Bonsall D, Fraser C (2020) Quantifying SARS-CoV-2 transmission suggests epidemic control with digital contact tracing. Science 368(6491):eabb6936. https://doi.org/10.1126/science. abb6936

Garazzino S, Montagnani C, Donà D, Meini A, Felici E, Vergine G, Bernardi S, Giacchero R, Lo Vecchio A, Marchisio P, Nicolini G, Pierantoni L, Rabbone I, Banderali G, Denina M, Venturini E,
Krzysztofiak A, Badolato R, Bianchini S, Galli L, Villani A, Castelli-Gattinara G, The Italian Sitip-Sip pediatric infection study G (2020) Multicentre Italian study of SARS-CoV-2 infection in children and adolescents, preliminary data as at 10 April 2020. Euro Surveill 25(18). https://doi.org/10.2807/1560-7917.Es.2020. 25.18.2000600

Gu J, Korteweg C (2007) Pathology and pathogenesis of severe acute respiratory syndrome. Am J Pathol 170(4):1136-1147. https://doi. org/10.2353/ajpath.2007.061088

Gu S, Chen Y, Wu Z, Chen Y, Gao H, Lv L, Guo F, Zhang X, Luo R, Huang C, Lu H, Zheng B, Zhang J, Yan R, Zhang H, Jiang H, Xu Q, Guo J, Gong Y, Tang L, Li L (2020) Alterations of the gut microbiota in patients with COVID-19 or H1N1 influenza. Clinical Infectious Diseases. https://doi.org/10.1093/cid/ciaa709

Huang C, Wang Y, Li X, Ren L, Zhao J, Hu Y, Zhang L, Fan G, Xu J, Gu X, Cheng Z, Yu T, Xia J, Wei Y, Wu W, Xie X, Yin W, Li H, Liu M, Xiao Y, Gao H, Guo L, Xie J, Wang G, Jiang R, Gao Z, Jin Q, Wang J, Cao B (2020) Clinical features of patients infected with 2019 novel coronavirus in Wuhan, China. The Lancet 395(10223): 497-506. https://doi.org/10.1016/S0140-6736(20)30183-5

Huttner B, Catho G, Pano-Pardo JR, Pulcini C, Schouten J (2020) COVID-19: don't neglect antimicrobial stewardship principles! Clin Microbiol Infect 26(7):808-810. https://doi.org/10.1016/j.cmi. 2020.04.024

Kalantar-Zadeh K, Ward SA, Kalantar-Zadeh K, El-Omar EM (2020) Considering the effects of microbiome and diet on SARS-CoV-2 infection: nanotechnology roles. ACS Nano 14(5):5179-5182. https://doi.org/10.1021/acsnano.0c03402

Kiedrowski MR, Bomberger JM (2018) Viral-bacterial co-infections in the cystic fibrosis respiratory tract. Front Immunol 9:3067. https:// doi.org/10.3389/fimmu.2018.03067

Kiley JL, Chung KK, Blyth DM (2020) Viral infections in burns. Surg Infect (Larchmt). https://doi.org/10.1089/sur.2020.130

Kim D, Quinn J, Pinsky B, Shah NH, Brown I (2020) Rates of Coinfection Between SARS-CoV-2 and Other Respiratory Pathogens. Jama 323:2085. https://doi.org/10.1001/jama.2020.6266

Klein EY, Monteforte B, Gupta A, Jiang W, May L, Hsieh YH, Dugas A (2016) The frequency of influenza and bacterial coinfection: a systematic review and meta-analysis. Influenza Other Respir Viruses 10(5):394-403. https://doi.org/10.1111/irv.12398

Lai CC, Shih TP, Ko WC, Tang HJ, Hsueh PR (2020a) Severe acute respiratory syndrome coronavirus 2 (SARS-CoV-2) and coronavirus disease-2019 (COVID-19): The epidemic and the challenges. Int J Antimicrob Agents 55(3):105924. https://doi.org/10.1016/j. ijantimicag.2020.105924

Lai CC, Wang CY, Hsueh PR (2020b) Co-infections among patients with COVID-19: The need for combination therapy with non-antiSARS-CoV-2 agents? J Microbiol Immunol Infect. https://doi.org/ 10.1016/j.jmii.2020.05.013

Li Z, He L, Li S, He W, Zha C, Ou W, Hou Q, Wang W, Sun X, Liang H (2019) Combination of procalcitonin and C-reactive protein levels in the early diagnosis of bacterial co-infections in children with H1N1 influenza. Influenza Other Respir Viruses 13(2):184-190. https://doi.org/10.1111/irv.12621

Li R, Pei S, Chen B, Song Y, Zhang T, Yang W, Shaman J (2020a) Substantial undocumented infection facilitates the rapid dissemination of novel coronavirus (SARS-CoV-2). Science 368(6490):489493. https://doi.org/10.1126/science.abb3221

Li X, Wang L, Yan S, Yang F, Xiang L, Zhu J, Shen B, Gong Z (2020b) Clinical characteristics of 25 death cases with COVID-19: a retrospective review of medical records in a single medical center, Wuhan, China. Int J Infect Dis 94:128-132. https://doi.org/10. 1016/j.ijid.2020.03.053

Li Y, Ren B, Peng X, Hu T, Li J, Gong T, Tang B, Xu X, Zhou X (2020c) Saliva is a non-negligible factor in the spread of COVID-19. Mol Oral Microbiol 35:141-145. https://doi.org/10.1111/omi.12289 
Lim YK, Kweon OJ, Kim HR, Kim TH, Lee MK (2019) Impact of bacterial and viral coinfection in community-acquired pneumonia in adults. Diagn Microbiol Infect Dis 94(1):50-54. https://doi.org/ 10.1016/j.diagmicrobio.2018.11.014

Lin D, Liu L, Zhang M, Hu Y, Yang Q, Guo J, Guo Y, Dai Y, Xu Y, Cai Y, Chen X, Zhang Z, Huang K (2020) Co-infections of SARS-CoV2 with multiple common respiratory pathogens in infected patients. Sci China Life Sci 63(4):606-609. https://doi.org/10.1007/s11427020-1668-5

Lippi G, Plebani M (2020) Procalcitonin in patients with severe coronavirus disease 2019 (COVID-19): A meta-analysis. Clin Chim Acta 505:190-191. https://doi.org/10.1016/j.cca.2020.03.004

Lu R, Zhao X, Li J, Niu P, Yang B, Wu H, Wang W, Song H, Huang B, Zhu N, Bi Y, Ma X, Zhan F, Wang L, Hu T, Zhou H, Hu Z, Zhou W, Zhao L, Chen J, Meng Y, Wang J, Lin Y, Yuan J, Xie Z, Ma J, Liu WJ, Wang D, Xu W, Holmes EC, Gao GF, Wu G, Chen W, Shi W, Tan W (2020) Genomic characterisation and epidemiology of 2019 novel coronavirus: implications for virus origins and receptor binding. Lancet 395(10224):565-574. https://doi.org/10.1016/s01406736(20)30251-8

Luo Y, Xie Y, Zhang W, Lin Q, Tang G, Wu S, Huang M, Yin B, Huang J, Wei W, Yu J, Hou H, Mao L, Liu W, Wang F, Sun Z (2019) Combination of lymphocyte number and function in evaluating host immunity. Aging (Albany NY) 11(24):12685-12707. https://doi. org/10.18632/aging.102595

Mahony JB (2008) Detection of respiratory viruses by molecular methods. Clin Microbiol Rev 21(4):716-747. https://doi.org/10. 1128/cmr.00037-07

Martins-Filho PR, Tavares CSS, Santos VS (2020) Factors associated with mortality in patients with COVID-19. A quantitative evidence synthesis of clinical and laboratory data. Eur J Intern Med 76:97-99. https://doi.org/10.1016/j.ejim.2020.04.043

Netea MG, Giamarellos-Bourboulis EJ, Domínguez-Andrés J, Curtis N, van Crevel R, van de Veerdonk FL, Bonten M (2020) Trained immunity: a tool for reducing susceptibility to and the severity of SARS-CoV-2 infection. Cell 181(5):969-977. https://doi.org/10. 1016/j.cell.2020.04.042

Ni L, Ye F, Cheng ML, Feng Y, Deng YQ, Zhao H, Wei P, Ge J, Gou M, Li X, Sun L, Cao T, Wang P, Zhou C, Zhang R, Liang P, Guo H, Wang X, Qin CF, Chen F, Dong C (2020) Detection of SARS-CoV2-specific humoral and cellular immunity in COVID-19 convalescent individuals. Immunity 52:971-977.e3. https://doi.org/10.1016/ j.immuni.2020.04.023

Nickbakhsh S, Mair C, Matthews L, Reeve R, Johnson PCD, Thorburn F, von Wissmann B, Reynolds A, McMenamin J, Gunson RN, Murcia PR (2019) Virus-virus interactions impact the population dynamics of influenza and the common cold. Proc Natl Acad Sci U S A 116(52):27142-27150. https://doi.org/10.1073/pnas.1911083116

Nicola M, O'Neill N, Sohrabi C, Khan M, Agha M, Agha R (2020) Evidence based management guideline for the COVID-19 pandemic - Review article. Int J Surg 77:206-216. https://doi.org/10.1016/j. ijsu.2020.04.001

Nikolich-Zugich J, Knox KS, Rios CT, Natt B, Bhattacharya D, Fain MJ (2020) SARS-CoV-2 and COVID-19 in older adults: what we may expect regarding pathogenesis, immune responses, and outcomes. 10 doi:https://doi.org/10.1007/s11357-020-00186-0

Nowak MD, Sordillo EM, Gitman MR, Paniz Mondolfi AE (2020) Coinfection in SARS-CoV-2 infected patients: where are influenza virus and rhinovirus/enterovirus? J Med Virol. https://doi.org/10. 1002/jmv.25953

Peng X, Xu X, Li Y, Cheng L, Zhou X, Ren B (2020) Transmission routes of 2019-nCoV and controls in dental practice. Int J Oral Sci 12(1):9. https://doi.org/10.1038/s41368-020-0075-9

Piva S, Filippini M, Turla F, Cattaneo S, Margola A, De Fulviis S, Nardiello I, Beretta A, Ferrari L, Trotta R, Erbici G, Focà E, Castelli F, Rasulo F, Lanspa MJ, Latronico N (2020) Clinical presentation and initial management critically ill patients with severe acute respiratory syndrome coronavirus 2 (SARS-CoV-2) infection in Brescia, Italy. J Crit Care 58:29-33. https://doi.org/10.1016/j.jcrc. 2020.04.004

Prestinaci F, Pezzotti P, Pantosti A (2015) Antimicrobial resistance: a global multifaceted phenomenon. Pathog Glob Health 109(7):309 318. https://doi.org/10.1179/2047773215y.0000000030

Qin C, Zhou L, Hu Z, Zhang S, Yang S, Tao Y, Xie C, Ma K, Shang K, Wang W, Tian DS (2020) Dysregulation of immune response in patients with COVID-19 in Wuhan. China. Clin Infect Dis 71: 762-768. https://doi.org/10.1093/cid/ciaa248

Rawson TM, Moore LSP, Zhu N, Ranganathan N, Skolimowska K, Gilchrist M, Satta G, Cooke G, Holmes A (2020) Bacterial and fungal co-infection in individuals with coronavirus: a rapid review to support COVID-19 antimicrobial prescribing. Clin Infect Dis. https://doi.org/10.1093/cid/ciaa530

Richardson S, Hirsch JS, Narasimhan M, Crawford JM, McGinn T, Davidson KW, Barnaby DP, Becker LB, Chelico JD, Cohen SL, Cookingham J, Coppa K, Diefenbach MA, Dominello AJ, DuerHefele J, Falzon L, Gitlin J, Hajizadeh N, Harvin TG, Hirschwerk DA, Kim EJ, Kozel ZM, Marrast LM, Mogavero JN, Osorio GA, Qiu M, Zanos TP (2020) Presenting characteristics, comorbidities, and outcomes among 5700 patients hospitalized with COVID-19 in the New York City Area. Jama 323:2052. https://doi.org/10.1001/ jama.2020.6775

Rodriguez JA, Rubio-Gomez H, Roa AA, Miller N, Eckardt PA (2020) Co-Infection with SARS-COV-2 and Parainfluenza in a young adult patient with pneumonia: case report. IDCases 20:e00762. https:// doi.org/10.1016/j.idcr.2020.e00762

Rouse BT, Sehrawat S (2010) Immunity and immunopathology to viruses: what decides the outcome? Nat Rev Immunol 10(7):514-526. https://doi.org/10.1038/nri2802

Ruuskanen O, Lahti E, Jennings LC, Murdoch DR (2011) Viral pneumonia. Lancet 377(9773):1264-1275. https://doi.org/10.1016/s01406736(10)61459-6

Salehi M, Ahmadikia K, Mahmoudi S, Kalantari S, Jamalimoghadam Siahkali S, Izadi A, Kord M, Dehghan Manshadi SA, Seifi A, Ghiasvand F, Khajavirad N, Ebrahimi S, Koohfar A, Boekhout T, Khodavaisy S (2020) Oropharyngeal candidiasis in hospitalized COVID-19 Patients from Iran: Species identification and antifungal susceptibility pattern. Mycoses 63:771-778. https://doi.org/10. 1111/myc. 13137

Shen Z, Xiao Y, Kang L, Ma W, Shi L, Zhang L, Zhou Z, Yang J, Zhong J, Yang D, Guo L, Zhang G, Li H, Xu Y, Chen M, Gao Z, Wang J, Ren L, Li M (2020) Genomic diversity of SARS-CoV-2 in Coronavirus Disease 2019 patients. Clin Infect Dis 71:713-720. https://doi.org/10.1093/cid/ciaa203

Singhal T (2020) A review of coronavirus disease-2019 (COVID-19). Indian J Pediatr 87(4):281-286. https://doi.org/10.1007/s12098020-03263-6

Tan L, Wang Q, Zhang D, Ding J, Huang Q, Tang YQ, Wang Q, Miao H (2020) Lymphopenia predicts disease severity of COVID-19: a descriptive and predictive study. Signal Transduct Target Ther 5(1):33. https://doi.org/10.1038/s41392-020-0148-4

Tay MZ, Poh CM, Rénia L, MacAry PA, Ng LFP (2020) The trinity of COVID-19: immunity, inflammation and intervention. Nature Reviews Immunology 20:363-374. https://doi.org/10.1038/ s41577-020-0311-8

Vareille M, Kieninger E, Edwards MR, Regamey N (2011) The airway epithelium: soldier in the fight against respiratory viruses. Clin Microbiol Rev 24(1):210-229. https://doi.org/10.1128/cmr.0001410

Verweij PE, Rijnders BJA, Brüggemann RJM, Azoulay E, Bassetti M, Blot S, Calandra T, Clancy CJ, Cornely OA, Chiller T, Depuydt P, Giacobbe DR, Janssen NAF, Kullberg BJ, Lagrou K, Lass-Flörl C, Lewis RE, Liu PW, Lortholary O, Maertens J, Martin-Loeches I, 
Nguyen MH, Patterson TF, Rogers TR, Schouten JA, Spriet I, Vanderbeke L, Wauters J, van de Veerdonk FL (2020) Review of influenza-associated pulmonary aspergillosis in ICU patients and proposal for a case definition: an expert opinion. Intens Care Med. https://doi.org/10.1007/s00134-020-06091-6

Wang M, Luo L, Bu H, Xia H (2020a) Case report: one case of coronavirus desease 2019(COVID-19) in patient co-nfected by HIV with a low CD4+ T cell count. Int J Infect Dis 96:148-150. https://doi.org/ 10.1016/j.jijid.2020.04.060

Wang M, Wu Q, Xu W, Qiao B, Wang J, Zheng H, Jiang S, Mei J, Wu Z, Deng Y, Zhou F, Wu W, Zhang Y, Lv Z, Huang J, Guo X, Feng L, Xia Z, Li D, Xu Z, Liu T, Zhang P, Tong Y, Li Y (2020b) Clinical diagnosis of 8274 samples with 2019-novel coronavirus in Wuhan. medRxiv:2020.02.12.20022327 doi:https://doi.org/10.1101/2020. 02.12 .20022327

Wiegers HMG, van Nijen L, van Woensel JBM, Bem RA, de Jong MD, Calis JCJ (2019) Bacterial co-infection of the respiratory tract in ventilated children with bronchiolitis; a retrospective cohort study. BMC Infectious Diseases 19(1):938. https://doi.org/10.1186/ s12879-019-4468-3

World Health O (2020) Laboratory testing for coronavirus disease 2019 (COVID-19) in suspected human cases: interim guidance, 2 March 2020. World Health Organization, Geneva

Xu R, Cui B, Duan X, Zhang P, Zhou X, Yuan Q (2020) Saliva: potential diagnostic value and transmission of 2019-nCoV. Int J Oral Sci 12(1):11. https://doi.org/10.1038/s41368-020-0080-Z

Yang X, Yu Y, Xu J, Shu H, Xia J, Liu H, Wu Y, Zhang L, Yu Z, Fang M, Yu T, Wang Y, Pan S, Zou X, Yuan S, Shang Y (2020) Clinical course and outcomes of critically ill patients with SARS-CoV-2 pneumonia in Wuhan, China: a single-centered, retrospective, observational study. Lancet Respir Med 8(5):475-481. https://doi.org/ 10.1016/s2213-2600(20)30079-5

Yetmar ZA, Issa M, Munawar S, Burton MC, Pureza V, Sohail MR, Mehmood T (2020) Inpatient Care of Patients with COVID-19: A
Guide for Hospitalists. Am J Med S0002-9343(20):30349-30341. https://doi.org/10.1016/j.amjmed.2020.03.041

Yuen KS, Ye ZW, Fung SY, Chan CP, Jin DY (2020) SARS-CoV-2 and COVID-19: the most important research questions. Cell Biosci 10: 40. https://doi.org/10.1186/s13578-020-00404-4

Zhang G, Hu C, Luo L, Fang F, Chen Y, Li J, Peng Z, Pan H (2020) Clinical features and short-term outcomes of 221 patients with COVID-19 in Wuhan, China. J Clin Virol 127:104364. https://doi. org/10.1016/j.jcv.2020.104364

Zheng Z, Chen R, Li Y, Liu X, He W, Xu Y, He G, Li Y, Luo Q, Zhong N (2003) The clinical characteristics of secondary infections of lower respiratory tract in severe acute respiratory syndrome. Chinese Journal of Respiratory and Critical Care Medicine 2(5):270-274

Zhou P, Liu Z, Chen Y, Xiao Y, Huang X, Fan XG (2020a) Bacterial and fungal infections in COVID-19 patients: a matter of concern. Infect Control Hosp Epidemiol:1-2 doi:https://doi.org/10.1017/ice.2020. 156

Zhou S, Wang Y, Zhu T, Xia L (2020b) CT features of Coronavirus Disease 2019 (COVID-19) pneumonia in 62 patients in Wuhan, China. AJR Am J Roentgenol 214(6):1287-1294. https://doi.org/ 10.2214/ajr.20.22975

Zhu N, Zhang D, Wang W, Li X, Yang B, Song J, Zhao X, Huang B, Shi W, Lu R, Niu P, Zhan F, Ma X, Wang D, Xu W, Wu G, Gao GF, Tan W (2020) A novel coronavirus from patients with pneumonia in China, 2019. N Engl J Med 382(8):727-733. https://doi.org/10. 1056/NEJMoa2001017

Zuo T, Zhan H, Zhang F, Liu Q, Tso EYK, Lui GCY, Chen N, Li A, Lu W, Chan FKL, Chan PKS, Ng SC (2020) Alterations in fecal fungal microbiome of patients with COVID-19 during time of hospitalization until discharge. Gastroenterology. https://doi.org/10.1053/j. gastro.2020.06.048

Publisher's note Springer Nature remains neutral with regard to jurisdictional claims in published maps and institutional affiliations. 